\title{
CAT SCRATCH DISEASE: THE FIRST CASE REPORT IN REPUBLIC OF NORTH MACEDONIA
}

\author{
Kostadin Poposki ${ }^{1}$, Zaklina Sopova ${ }^{1}$, Marija Dimzova ${ }^{1}$, \\ Elena Denkovska ${ }^{1}$, Tatjana Stoleska², Mile Bosilkovski ${ }^{1}$ \\ ${ }^{1}$ University Clinic for Infectious Diseases and Febrile Conditions, Faculty of Medicine "Ss. Cyril and Methodius", Skopje, \\ Republic of North Macedonia \\ ${ }^{2}$ Faculty of Natural Sciences and Mathematics, "Ss. Cyril and Methodius”, Skopje, Republic of North Macedonia
}

Corresponding author: Corresponding author: Kostadin Poposki, University Clinic for Infectious Diseases and Febrile Conditions, Faculty of Medicine, University "Ss. Cyril and Methodius", Skopje, Republic of North Macedonia, Mother Theresa Str no. 17, 1000 Skopje. Tel: + 389712236 03, Fax: + 3892 3228224, E-mail: kostadin. poposki@hotmail.com

\begin{abstract}
Cat scratch disease (CSD) is the main clinical manifestation caused by Bartonella henselae in immunocompetent patients. The bacterium is transmitted to humans from cats via scratches or bites. In this case report, we are presenting to our knowledge the first etiologically confirmed case of CSD in our country. Here we describe the case of a previously healthy adult female patient presenting with fever and axillar lymphadenopathy over 1-month period. She underwent numerous clinical and paraclinical investigations for potential etiologies associated with lymphadenopathy and fever. Finally, serological testing for B.henselae was performed with titers for IgG 1:1024 and 1:160 for IgM, which confirmed the diagnosis. Five-day treatment with azithromycin resulted with good clinical response and complete recovery. We proved that CSD is a reality in our country and this report should raise awareness in medical doctors, especially infectious disease specialist. Also, CSD should be included in differential diagnosis in patients with fever of unkown origin (FUO), who are presenting with regional lymphadenopathy, with or without history of cat contact.
\end{abstract}

Keywords: cat scratch disease; bartonella henselae; lymphadenopathy; fever of unknown origin

\section{INTRODUCTION}

Cat scratch disease (CSD) is a zoonotic disease caused by Bartonella henselae, an intracellular, gram negative bacterium which is transmitted to humans from cats via scratches and bites [1,2]. CSD was described clinically for the first time in 1931 by Robert Debre, in a boy with suppurative adenitis in the epitrochlear region and severe cat scratches on the ipsilateral hand [3], but the etiologic agent remained unknown until 1983, when pleomorphic gram-negative bacilli were detected with silver impregnation strains (Warthin-Starry method) from lymph nodes in patients with CSD [4]. Later, more advanced serologic, microbiologic and molecular studies provided evidence that Bartonella henselae was the major etiologic agent of CSD [5].

Presentation and severity of the disease is closely related to the patients' immune status [6]. In $90 \%$ of the immunocompetent patients, typical form of CSD tends to develop with a characteristic papule or pustule at a site of injury, 3 to 10 days after animal contact [7]. This is followed by ipsilateral regional lymphadenopathy proximal of inoculation site, with or without constitutional symptoms $[7,8]$. This form of CSD usually is benign and self-limiting, 
with regression of the lymphadenopathy within 2 to 6 months. Some patients however, may have prolonged fever and concomitant constitutional symptoms. In immunocompromised patients, especially in AIDS, systemic inflammatory response to bacilli develops; either as vascular proliferative lesion within the skin, bone (bacillary angiomatosis) or solid internal organs with reticuloendothelial elements, primarily the liver (bacillary peliosis) $[7,9,10]$.

Our aim was to describe a case with CSD and to raise awareness, especially in patients with history of recent cat contact who are presenting with regional lymphadenopathy.

\section{CASE REPORT}

A previously healthy 51 years old female patient has presented with left axillary lymphadenopathy, mid to low-grade fever, myalgia, malaise, fatigue and loss of appetite. There were no underlying diseases and no drugs or alcohol abuse. She had no history of recent travel. The disease started abruptly, without organ specific manifestations. One week after the initial symptoms, she was seen by primary care physician. On physical exam she was febrile, in relatively good condition, with enlarged lymph node in her left axilla; no fluctuance was noted. Laboratory analysis showed erythrocyte sedimentation rate (ESR) of $45 \mathrm{~mm} / \mathrm{hr}$, white blood cells (WBC) 6.5 x109/L, with normal differential cell count and normal serum chemistries. The patient was empirically treated with cefixime in 10-day period.

With still persisting fever and no size reduction of the lymph node, the patient was referred to infectious disease specialist at the regional hospital three weeks after the initial symptoms. Serological studies for Cytomegalovirus, Epstein-Barr virus, Herpes simplex virus, Hepatitis B and $\mathrm{C}$ viruses, Human immunodeficiency virus (HIV), Toxoplasma gondii, Echinococcus and Brucella spp. were negative. Cultures of blood samples and urine remained sterile. Additionally, laboratory investigations of thyroid hormones (TSH, T3 and T4) and tumor markers (CEA, CA 15-3 and CA 125) were made, all within normal ranges. Mammogram and breast ultrasound showed normal findings, chest computed tomography (CT) scan revealed packaged lymph nodes in the left axilla. The abdominal CT was normal.

One month after the initial symptoms, with persisting fever up to $38.50 \mathrm{C}$ and the existing lymphadenopathy, the patient was referred as outpatient to the Clinic for Infectious diseases and febrile condition in Skopje. She lost $5 \mathrm{~kg}$ over this period. On examination she was febrile $-380 \mathrm{C}$, in relatively good condition with no acute distress. The physical exam showed enlarged left axillar lymph node; walnut-shaped, movable, elastic, without redness or tenderness (Figure 1).

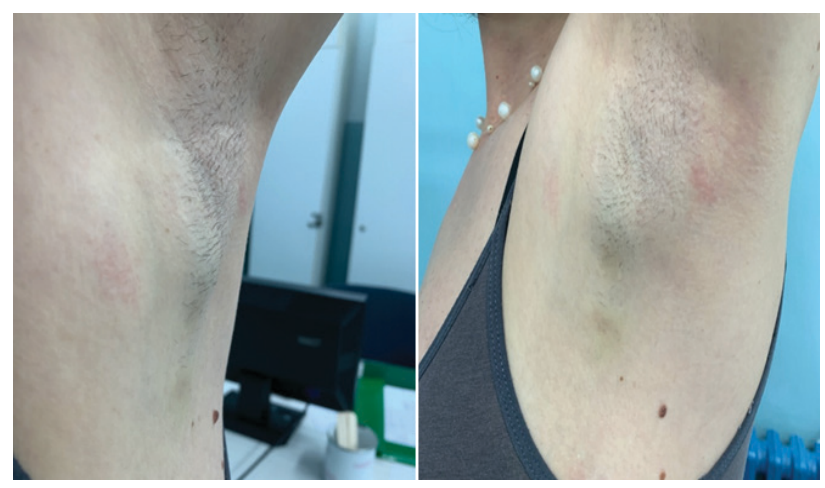

Figure 1. Frontal and profile images show axillar lymphadenopathy without signs of inflammation

Other physical status was unremarkable. Laboratory investigation demonstrated ESR $35 \mathrm{~mm} / \mathrm{hr}$, WBC $3.5 \times 109 / \mathrm{L}$, with 0.29 neutrophils and 0.61 lymphocytes. Her platelet count was $152 \times 109 / \mathrm{L}$; hematocrit 0.44; and C-reactive protein (CRP) 25 $\mathrm{mg} / \mathrm{L}$. Liver function tests and other biochemical analysis were normal. During anamnestic re-evaluation, the patient revealed that 3 cats resided in her home. She also recalled appearance of erythematous papules on her left hand, 2 weeks prior to lymphadenopathy appeared. With no available serology for B. henselae at that time, we proceeded the diagnostic workup for fever of unknown origin (FUO). Additional visceral Leishmaniasis, Tularemia, Syphilis and Lyme disease were excluded. Peripheral blood smear was made and no atypical or malignant cells were found. Later, fine needle aspiration of the lymph node was initiated and showed no granuloma or malignant cells. Also, the patient was seen by tuberculosis specialist and tuberculosis was excluded.

On the next follow up, we recommended serology testing for CSD in reference laboratory abroad. Serum sample was sent for B. henselae, and indirect immunofluorescence antibody (IFA) were positive for $\operatorname{IgG}(1: 1024$, normal 1:64) and $\operatorname{IgM}(1: 60$, normal values up to 1:20). Treatment with azithromycin was started (500 mg once a day) for 5 days. Fourteen days after the treatment, the temperature subsided with no constitutional symptoms and with noticeable size reduction of the lymph node. After 2-month follow up, there were no recurrences, the lymph node was non-palpable and the patient recovered completely.. 


\section{DISCUSSION}

In this presentation we reported, according to our knowledge, the first etiologically confirmed case with CSD in the Republic of North Macedonia. This report comes almost 30 years after association between B. henselae and CSD was made. This delay is mainly because diagnostic methods for B. henselae in our country are still not easily accessible. Consequently to this, general physicians and even infectious disease specialists have low awareness about CSD and $\mathrm{B}$. henselae in general. This leads to misdiagnosis, prolonged antibiotic use and increased morbidity.

CSD occurs worldwide, but the incidence of the disease is not known in our country for reasons already mentioned above. In the USA, the annual incidence is 4.7 patients per 100.000 population, and appears dominantly in late summer and fall [11]. The seroprevalence of $\mathrm{B}$. henselae is relatively high among healthy individuals, with reports showing positive $\operatorname{IgG}(>1: 64)$ in $8.7 \%$ in Spain [12], $16 \%$ in Sweden [13], 19.6\% in China [14], 15\% in Korea [15], with majority of the study participants owning cat in their residence $[13,14,15]$. CSD occurs primarily in young children and adolescents [1], but recent data suggest that CSD may be more common among adults, as was presented in our case.

The hallmark of CSD is regional lymphadenopathy, proximal from inoculation site. Most commonly affected lymph nodes are those in the axilla $(46 \%)$, head and neck (26\%), and the groin (17.5\%), with single node involvement in $85 \%$ of the patients [16]. However, Tsuneoka et al. [17] in a study with 156 serologically confirmed cases of CSD, reported that $16.1 \%$ (30 patients) had no lymphadenopathy. In some patients, including ours, cat-scratch disease can be presented as fever of unknown origin (FUO) $[17,18]$. B.henselae is well recognized cause of FUO in both pediatric and immunocompetent adults, so it should be considered in the differential diagnosis in the patients with FUO, with and without potential diagnostic clues (lymphadenopathy, contact with cats) $[17,18]$.

The diagnosis of CSD requires 3 of the 4 criteria: (1) cat contact with or without scratch mark or a regional inoculation lesion; (2) negative laboratory, radiology and serologic studies for infectious or other diseases as causes of adenopathy; (3) positive indirect fluorescent antibody assay serology test for B. henselsae; (4) biopsy of lymph node showing granulomatous inflammation [7].
The first and the least expensive step in the diagnosis of CSD is the anamnestic investigation with attention to patients' cat contact. As shown in our case, no adequate history taking (till the tertiary care admission) led to unnecessary antibiotics use, increased uncertainty in our patient about her prognosis, as well the expense of time and money. We didn't detect the inoculation site, and was neither reported by the primary care physician in their first encounter. The inoculation site can often heal prior appearance of lymphadenopathy, which is often the first reason patients seeks medical attention. There are variable results regarding the presence of an inoculation site, ranging from 61\% (807 patients) in Margileths' et al. [20] study to $92 \%$ in Carithers' [21] study performed on 1000 patients. The second criteria was met as all available differential diagnostics excluded various causes of lymphadenopathy (especially unilateral), among which are pyogenic bacteria, infectious mononucleosis, tularemia, brucellosis, toxoplasmosis, mycobacterial infectious, syphilis, histoplasmosis, lymphoma, lymphoproliferative diseases and other neoplasm. Our fine needle aspiration showed no granulomas or stellate necrosis, which are the histopathological hallmarks of CSD [7,16]. This is because fine needle aspiration has the lowest percent of accuracy compared to core and surgical biopsy in the diagnosis of soft tissue masses [22]. The bacilli can be demonstrated with silver staining (Warthin-Starry or Steiner method) $[8,23]$ but unfortunately, this method was out of use in our microbiological laboratories. The inability to demonstrate granuloma formation, in our opinion, is the main downfall of this report.

The most practical method of confirming CSD is serologic testing by indirect fluorescent assay (IFA) or enzyme-linked immunosorbent assay (EIA) $[24,25]$. Unfortunately, both tests are hampered by variable sensitivity and specificity. This is because there is high seroprevalence in healthy individuals, as mentioned above, and high cross-reactivity with B. quintana and Chlamydia spp [26,27). However, with two or more criteria fulfilled, the sensitivity is up to $71 \%$ [25,27]. Immunoglobulin $\mathrm{G}$ (IgG) titers for B. henselae above 1:256 and immunoglobulin M (IgM) titers above 1:20 suggest active or recent infection. In our case, we conducted IFA serology for B. henselae antibodies. IgG titer was 1:1024 and 1:160 titer for $\operatorname{IgM}$. This result combined with positive epidemiology and excluded other causes of lymphadenopathy strongly confirmed our diagnosis.

The treatment of CSD is not always necessary, because the adenopathy is benign and self-limited. In moderate to severely ill patients, with prolonged 
constitutional symptoms and organ involvement, antibiotic treatment can be helpful. There are reports observing good clinical response from rifampin, TMP-SMZ, gentamicin and azithromycin [28,29,30]. Arsoy at al. [28] reported defervescence and clinical improvement within 1-5 days treatment with rifampin, with or without TMP-SMZ in pediatric patient with hepatosplenic CSD. Margileth et al. [29] retrospectively observed reduction of mean duration of illness to 2.8 weeks in patients treated with gentamicin, ciprofloxacin, rifampin or TMP-SMZ, compared to 14.5 weeks duration in patients treated with other unresponsive antibiotics. Prospective, double-blind, placebo-controlled study performed by Bass et al. [30] observed the effect of azithromycin in immunocompetent patient with uncomplicated CSD. This study showed $80 \%$ decrease in lymph node volume in 7 out of 14 azithromycin treated patients compared to 1 out of 15 placebo-group patients, for a period of 30 days $(\mathrm{P}=0.026)$. The clinical outcome from both groups was comparable. We also observed good clinical improvement with azithromycin, with noticeable volume reduction of the lymph node in 2-week period and complete regression of lymph node within 2-month period.

In conclusion, our general physicians, infectious disease specialists and health authorities have low awareness about CSD. With its broad spectrum of clinical manifestations, CSD must be suspected and thought in cat owners, especially pediatric and immunocompromised patients. Our intention with this report is to suggest that CSD is reality in the Republic of North Macedonia and should be included in the differential diagnosis in patients with FUO and lymphadenopathy.

\section{REFERENCES}

1. Chommel BB. Cat-scratch disease. Rev Sci Tech 2000; 19(1): 136-50.

2. Windsor JJ. Cat-scratch disease: epidemiology, aetiology and treatment. Br J Biomed Sci 2001; 58: 101 .

3. Debré R, Lamy M, Jammet ML, et al. La maladie des griffes de chat. Bull, Membres Soc méd Hôp Paris 1950; 66: 76-79.

4. Wear DJ, Margileth AM, Hadfield T.L, et al. Cat scratch disease: a bacterial infection. Science 1983; 221: 1403-1405.

5. Regnery RL, Olson JG, Bradley AP, et al. Serological response to "Rochalimaea henselae" antigen in suspected cat-scratch disease. Lancet 1992; 339: 1443-1445.
6. Bass JW, Vincent JM, Person DA. The expanding spectrum of bartonella infections: II cat-scratch disease. Pediatr Infect Dis J 1997; 16: 163-179.

7. Andrew M, Margileth MD. Recent Advances in Diagnosis and Treatment of Cat Scratch Disease. Current Infectious Disease Reports 2000; 2: $141-146$

8. Carithers HA, Carithers CM, Edwards RO. Catscratch disease: its natural history. JAMA 1969; 207: 312-316.

9. Biancardi AL, Curi AL. Cat-Scratch Disease. Ocul Immunol Inflamm 2014; 22(2): 148-154.

10. Wong MT, Dolan MJ, Lattuada CP et al. Neuroretinitis, aseptic meningitis, and lymphadenitis associated with Bartonella (Rochalimaea) henselae infection in immunocompetent patients and patients infected with human immunodeficiency virus type 1. Clin Infect Dis 1995; 21(2): 352-60.

11. Nelson CA, Saha S, Mead PS. Cat-Scratch Disease in the United States, 2005-2013. Emerg Infect Dis 2016; 22(10): 1741-1746.

12. Pons I, Sanfeliu I, Cardenosa N, et al. Serological evidence of Bartonella henselae infection in healthy people in Catalonia, Spain. Epidemiol Infect 2008; 136: 1712-1716.

13. McGill S, Wesslen L, Hjelm E, et al. Bartonella spp. seroprevalence in healthy Swedish blood donors. Scand J Infect Dis 2005; 37: 723-730.

14. Liu Q, Eremeeva ME, Li D. Bartonella and Bartonella infections in China: from the clinic to the laboratory. Comp Immunol Microbiol Infect Dis 2012; 35: 93-102.

15. Kwon HY, Im JH, Lee SM, et al. The seroprevalence of Bartonella henselae in healthy adults in Korea. Korean J Intern Med 2017; 32: 530-535.

16. Mandell GL, Douglas RG, Bennett JE, et al. Mandell, Douglas, and Bennett's Principles and Practice of Infectious Diseases. Philadelphia Elsevier 2015; 8(2): 3566-3585.

17. Tsuneoka $\mathrm{H}$, Tsukahara M. Analysis of data in 30 patients with cat scratch disease without lymphadenopathy. J Infect Chemother 2006; 12: 224226.

18. Zenone T. Systemic Bartonella henselae Infection in Immunocompetent Adult Presenting as Fever of Unknown Origin. Case Rep Med 2011; 2011:183937.

19. Tolia J, Smith LG. Fever of Unknown Origin: Historical and Physical Clues to Making the Diagnosis. Infect Dis Clin N Am 2007; 21: 917-936.

20. Margileth AM. Dermatologic manifestations and update of cat scratch. Pediatr Dermatol 1988; 5(1): 1-9.

21. Carithers HA. Cat-scratch disease. An overview based on a study of 1,200 patients. Am J Dis Child 1985; 139(11): 1124-1133.

22. Kasraeian S, Allison CD, Ahlmann ER, et al. A Comparison of Fine-needle Aspiration, Core Bi- 
opsy, and Surgical Biopsy in the Diagnosis of Extremity Soft Tissue Masses. Clin Orthop Relat Res 2010; 468: 2992-3002.

23. Margileth AM. Cat-scratch disease update. Am J Dis Child 1984; 138: 711-713.

24. Margileth AM. Recent advances in diagnosis and treatment of cat scratch disease. Curr Infect Dis Rep 2000; 2: 141-146.

25. Herremans M, Vermeulen MJ, Van de Kassteele $\mathrm{J}$, et al. The use of Bartonella henselae-specifi c age dependent IgG and IgM in diagnostic models to discriminate diseased from non-diseased in Cat Scratch Disease serology. J Microbiol Methods 2007; 71: 107-113.

26. Sander A, Posselt M, Oberle K, et al. Seroprevalence of antibodies to Bartonella henselae in patients with cat scratch disease and in healthy controls: evaluation and comparison of two commercial serological tests. Clin Diagn Lab Immunol 1998; 5: 486-490.
27. Bergmans AMC, Peeters MF, Schellenkens JFP, et al. Pitfalls and fallacies of cat scratch disease serology: evaluation of Bartonella henselae-based indirect fluorescence assay and enzyme-linked immunoassay. J Clin Microbiol 1997, 35: 1931-1937.

28. Arisoy ES, Correa AG, Wagner ML, et al. Hepatosplenic cat-scratch disease in children: selected clinical features and treatment. Clin Infect Dis 1999; 28: 778-784.

29. Margileth AM. Antibiotic therapy for cat-scratch disease: clinical study of therapeutic outcome in 268 patients and a review of the literature. Pediatr Infect Dis J 1992; 11(6): 474-478.

30. Bass JW, Freitas BC, Freitas AD, et al. Prospective randomized double blind placebo-controlled evaluation of azithromycin for treatment of catscratch disease. Pediatr Infect Dis J 1998; 17: 447-52.

\title{
Резиме
}

\section{БОЛЕСТ НА ГРЕБАНИЦА ОД МАЧКА: ПРВИОТ ПРИКАЗ НА СЛУЧАЈ ВО РЕПУБЛИКА СЕВЕРНА МАКЕДОНИЈА}

\author{
Костадин Попоски ${ }^{1}$, Жаклина Шопова ${ }^{1}$, Марија Димзова $^{1}$, \\ Елена Денковска ${ }^{1}$, Татјана Столеска ${ }^{2}$, Миле Босилковски $^{1}$
}

${ }^{1}$ Универзитетска клиника за инфективни болести и фебрилни состојби, Медицински факултет, Универзитет „Св. Кирил и Методиј“, Скопје, Република Северна Македонија

${ }^{2}$ Природно-математички факултет, Универзитет „Св. Кирил и Методиј“, Скопје, Република Северна Македони ${ }^{\mathrm{ja}}$

Болест на гребаница од мачка (БГМ) е главна клиничка манифестација на Bartonella henselae кај имунокомпетентни пациенти. Бактеријата се пренесува на човекот од мачки преку каснување или преку гребење. Тука го прикажуваме, колку што ни е познато, првиот етиолошки потврден случај на БГМ во нашата земја. Опишуваме случај на претходно здрава возрасна пациентка со температура и аксиларна лимфаденопатија во траење од еден месец. Направени беа бројни клинички и параклинички испитувања за докажување на потенцијалните причинители на лимфаденопатијата. На крајот, серолошкото тестирање за B.henselae покажа титар за IgG 1:1024 и 1:160 за IgM, со што дијагнозата беше поставена. Петдневниот третман со азитромицин резултираше со добар клинички одговор и комплетно оздравување. Покажавме дека БГМ е реалност во нашата земја, а овој случај треба да послужи во подигнувањето на знаењето за болеста кај лекарите во нашата земја, особено кај инфектолозите. Дополнително, БГМ треба да биде вклучена во диференцијалната дијагностика кај пациенти со треска од непознато потекло и регионална лимфаденопатија, со податок за контакт со мачка или без него.

Клучни зборови: болест на гребаница од мачка, лимфаденопатија, треска од непознато потекло 